\title{
Childhood Participation Experiences in the Memory
}

M. Gómez, T. Morata and J. Trilla

Theory and History of Education Department, University of Barcelona, Barcelona, Spain

Ramon Llull University, Barcelona, Spain

Theory and History of Education Department, University of Barcelona, Barcelona, Spain

Full correspondence details:

Miquel Gómez

Dept. de Teoria i Història de l’Educació

Facultat d'Educació (Universitat de Barcelona)

Campus Mundet

Passeig de la Vall d'Hebron, 171

08035-Barcelona

Spain

mgomez@ub.edu

Funding

This work was supported by the Spanish Ministerio de Ciencia e Innovación [Ministry of Science and Innovation] (Fundamental Research Projects ref. EDU2009-10967) 


\title{
Recalling Childhood Participatory Experiences
}

\begin{abstract}
This article is based on the findings of a broader research project entitled "Childhood Participation and Citizenship Building", which examined the medium-term effects of intense experiences of participation in childhood within both the school environment and those of leisure-time and community education. The results presented in this article refer specifically to the memories subjects hold of their participation in these childhood experiences. The study combined quantitative (using a questionnaire) and qualitative approaches (conducting in-depth interviews). The results obtained contribute to strengthening the idea explicit or implicit in all pedagogies that seek to promote child participation - that such participation is not only a right, but that it also contributes to the quality of educational experiences..
\end{abstract}

Keywords: child participation, leisure-time education, school, children's councils, memories

\section{Introduction}

"If I am to be honest, the entire period of my schooling was nothing other than a constant and wearisome boredom, accompanied year after year by an increased impatience to escape from this treadmill. I cannot recall ever having been either "joyous" or "blissful" during that monotonous, heartless and lifeless schooling which thoroughly spoiled the best and freest period of our existence. (...) For us, school was compulsion, tedious monotony and dreariness, a place where we had to assimilate the "science of the not-worth-knowing" in exactly measured 
portions - scholastic or scholastically manufactured material which we felt could have no relation to reality or to our personal interests. (...) And the only truly joyful moment of happiness for which I have to thank my school was the day I was able to shut the door behind me forever".

(Zweig 2001, 51-52)

In his memoir The Memory Chalet, leading European intellectual, Tony Judt, recalls the "grim" institution he attended "six times a week (...) for nearly seven years", with the poignant words: "I hated school" (Judt 2010, 97). And after cataloguing the moral, cultural and educational miseries inflicted on him by that institution, in an almost exact mirroring of Stefan Zweig's experiences, the British historian refers to the day he was finally able to leave that school in the following terms: "I recall few happier moments" (Judt 2010, 100).

Fortunately, much more favourable accounts of life at school than the recollections of Judt and Zweig can be found. And a good number do recall with evident nostalgia the many happy moments spent at school, their authors being keen to express their gratitude to both the institution and its teachers for the education received. Yet, what stands out in 19th and 20th century narrative - be it in fiction or memoirs are the number of descriptions and judgments of a bitter, negative nature. ${ }^{1}$ As in this eloquent paragraph from Virginia Woolf(1882-1941) in The Waves (1931):

\footnotetext{
${ }^{1}$ This is readily confirmed in the numerous compilations of literary texts about schooldays (for example, Lass and Tasman 1981; Craig, ed. 1994; Lomas 2011) and studies dedicated to their analysis (Barone 1988; Jackson and Haroutinian-Gordon, eds. 1989; Trilla 2002; Viñao 2002).
} 
“'It is the first day of the summer holidays,' said Susan. 'But the day is still rolled up. I will not examine it until I step out on to the platform in the evening. I will not let myself even smell it until I smell the cold green air off the fields. But already these are not school fields; these are not school hedges; the men in these fields are doing real things; they fill carts with real hay; and those are real cows, not school cows. But the carbolic smell of corridors and the chalky smell of schoolrooms is still in my nostrils. The glazed, shiny look of matchboard is still in my eyes. I must wait for fields and hedges, and woods and fields, and steep railway cuttings, sprinkled with gorse bushes, and trucks in sidings, and tunnels and suburban gardens with women hanging out washing, and then fields again and children swinging on gates, to cover it over, to bury it deep, this school that I have hated."' (Woolf 1931, 36)

In few yet so poetic lines, Virginia Woolf expresses some of the features of this traditional school that she - and many others - remembered with hatred: how it isolated itself from its surroundings to become a world apart, how it distorted and falsified reality and everything it touched ("those are real cows, not school cows..."). It is not without significance that a famous Spanish contemporary of Woolf's, Azorín (18731967) expressed the same separation of school and reality:

"It was ... where was it? It was a little village on the eastern coast of Spain; the school was located at one end, adjacent to the market garden (...). Every morning, just after the sun has risen over the distant blue mountains in this clear blue sky, the children go to school; (...) slowly, very slowly, savouring with delight these moments of complete freedom, delaying as much as possible their painful and inexorable captivity. But captivity is precisely what it is: we remember it as a vivid, disquieting image (...). 
Now we are in school: there is a cheerful, noisy buzz of voices. And suddenly we all fall silent: the teacher has appeared at the door. And the painful torment begins. Who can fail to remember? Is there anyone who does not recall those agonising efforts to retain what we do not understand - mysterious theodicy or arcane elementary arithmetic those endless repetitions, that ordeal of remaining still and quiet for hours on end, those silent and inexplicable sobs in which we unburden our first disappointments in life, that sudden bitterness which appears for the first time to muddy our clear, naive visions? Outside, the splendour of nature lives on: the trees are beautiful with their dense, round foliage, the birds sing, the mountains stand out strikingly in the bright daylight, the water trickles, murmuring along the ditches ..." (Azorín 1972, 222-224)²

And if Azorín spoke of captivity, another British author, George Bernard Shaw (1856-1950), directly compared the schools of his time to prisons:

"They send their children to school; and there is, on the whole, nothing on earth intended for innocent people so horrible as a school. To begin with, it is a prison. But it is in some respects more cruel than a prison. In a prison, for instance, you are not forced to read books written by the warders and the governor (who of course would not be warders and governors if they could write readable books), and beaten or otherwise tormented if you cannot remember their utterly unmemorable contents. In the prison you are not forced to sit listening to turnkeys discoursing without charm or interest on subjects that they don't understand and don't care about, and are therefore incapable of making you understand or care about. In a prison they may torture your body; but they

\footnotetext{
2 The book Artículos olvidados de J. Martinez Ruiz (1894-1904) was published in 1972, but the
} article in which the quotation appears is from 1903. 
do not torture your brains; and they protect you against violence and outrage from your fellow prisoners. In a school you have none of these advantages. With the world's bookshelves loaded with fascinating and inspired books, the very manna sent down from Heaven to feed your souls, you are forced to read a hideous imposture called a school book, written by a man who cannot write: a book from which no human being can learn anything: a book which, though you may decipher it, you cannot in any fruitful sense read, though the enforced attempt will make you loathe the sight of a book all the rest of your life. With millions of acres of woods and valleys and hills and wind and air and birds and streams and fishes and all sorts of instructive and healthy things easily accessible, or with streets and shop windows and crowds and vehicles and all sorts of city delights at the door, you are forced to sit, not in a room with some human grace and comfort or furniture and decoration, but in a stalled pound with a lot of other children, beaten if you talk, beaten if you move, beaten if you cannot prove by answering idiotic questions that even when you escaped from the pound and from the eye of your gaoler, you were still agonizing over his detestable sham books instead of daring to live." (Shaw 1910) ${ }^{3}$

We could add pages and pages of such pejorative descriptions, opinions and memories of the schools of yesteryear. But this polarisation of memories can be understood in two possible ways which we shall refer to as the objectivist and relativist interpretations. The former gives us to understand that if school days are recalled with such displeasure (or pleasure, as the case may be), it is because that is exactly how they

\footnotetext{
${ }^{3}$ The piece by Bernard Shaw is taken from a text published by the writer as a prologue to his play Misalliance (1910). It is included in his essay A Treatise on Parents and Children (http://www.gutenberg.org/files/908/908-h/908-h.htm\#link2H_4_0010)
} 
were experienced and it was the school that was chiefly responsible for their being experienced in that way. The relativist interpretation, by contrast, has reservations about the direct linear nature of this relationship, and claims that it cannot simply be accepted that what is remembered coincides exactly with what was experienced, or that the reason it was experienced in one way or the other was due solely to the institutional framework in which the individual's school days were played out.

The Spanish psychiatrist, Castilla del Pino, points out that memories are evocations of past events. That is, they are representations that do not necessarily coincide with what actually happened: "We recall things in different ways according to (1) the conditions in which we found ourselves when the events took place; (2) the type of event; and (3), the relationship that exists between the event being remembered and the moment in which the memory is evoked" (Castilla del Pino 2006, 17). We should clarify, as indeed Castillo del Pino does, that because what is being recalled fails to coincide precisely with the event actually experienced, this does not necessarily mean the memory is false or, worse still, that the person remembering it sets out with the intention of deceiving others or themselves.

This is not the place to explore the numerous mechanisms of the memory and their distortions, which have been and continue to be widely studied within a variety of disciplines. ${ }^{4}$ But shifting the focus back to the subject specifically addressed in this article, namely, the content and judgments present in recollections of childhood

\footnotetext{
${ }^{4}$ There is a branch of psychology specialised in the study of what is known as autobiographical memory (Baddeley 2010; Thompson, Herrmann, Bruce et al. 1998; Manzanero 2008).

Historiography - and specifically the epistemology of history - has also not ignored questions concerning the reliability of memory (Le Goff 1992; Alted 1996; Ricoeur 2004; Mudrovcic 2005).
} 
educational experiences, it is worth stressing that the interpretive framework of the rest of this paper combines the objectivist and relativist interpretations introduced above.

It is apparent that a certain amount of credibility ought to be given to these memories and judgments. Thus, if, for instance, it turns out that various generations overwhelmingly coincide in harbouring far from fond memories of their school days, it must be accepted that this does not speak well of the schools they attended. ${ }^{5}$ And if the opposite is true of subsequent generations, it should be acknowledged that the schools of their childhood must have borne little resemblance to the deplorable schools of their predecessors. Nevertheless, it ought not to be forgotten that memories are personal constructs built and rebuilt according to the moment in which they are reactivated.

Here, by combining the two interpretive focuses, this paper is able to examine the reality of the educational contexts in which participative educational experiences were had, while exploring aspects of the moment in which they are recalled and the personal characteristics of the individual recalling them ${ }^{6}$. And although in introducing

\footnotetext{
${ }^{5}$ Antonio Viñao uses well-chosen examples to refer to the shared memory that each generation holds of its school experiences in the context of Spain's education system in the $20^{\text {th }}$ century. (Viñao 2011)

${ }^{6}$ In other sections we have indicated a possible slant as regards the origin of school memories converted into literature (be it fiction or in memoirs). Those whose school memories we know best (because they are also those who have engaged most in publishing them) are writers, intellectuals and, in general, people from the world of culture and art. In other words, people with a generally more developed critical sensitivity and spirit for whom the encounter with a highly disciplined and regulated world such as that of the traditional school must have been especially difficult and emotional. "The image that men and women of letters offer us of the school should not be considered necessarily representative of the image the average pupil would give us. Because they are former pupils who, to a certain extent, when talking of the school do so from a privileged position, with the effectiveness and lucidity endowed upon them by their skills as writers." (Carbonell, Torrents, Tort and Trilla eds. 1987, 23).
} 
this discussion above the focus has been on somewhat distant memories, the following sections will consider the memory of much more recent educational experiences. To be precise, the aim of this article is to present the relevant findings from a broader piece of research, which we summarise below. ${ }^{7}$

\section{Child participation and building citizenship}

This study seeks to examine the medium-term effects of intense participation experiences in three educational environments during childhood: namely, those of school, leisure-time education (and, specifically, the Catalan esplais) and municipal children's councils (see below for full explanation).

But first we should specify certain concepts related to participation. Thus, according to UNICEF: "Child participation must be authentic and meaningful. It must start with children and young people themselves, on their own terms, within their own realities and in pursuit of their own visions, dreams, hopes and concerns. Most of all, authentic and meaningful child participation requires a radical shift in adult thinking and behaviour - from an exclusionary to an inclusionary approach to children and their capabilities." 8

Casas, following Lansdown (2001), summarises the main features of "effective participation" as follows: the topic must have real relevance to children and the young; it must provide a differential element (such as having results and generating long-term institutional change); it must be linked to the everyday experiences of children and the young; it must have sufficient material and time resources; it must generate realistic

\footnotetext{
${ }^{7}$ Trilla et al.: Participación infantil y construcción de la ciudadanía. Spanish Ministry of Science and Innovation, Fundamental Research Projects, ref. EDU2009-10967.

${ }^{8}<\underline{\text { http://www.unicef.org/sowc03/contents/childparticipation.html }>}$
} 
expectations for children and the young; it must have objectives which are both clear and negotiated with children and the young; it must be directed to the promotion and protection of children's rights; it must have support from adults when necessary; and the methodology employed must be developed in collaboration with the children and young people." (Casas et al. 2008, 365-366)

Trilla and Novella distinguish between four types or levels of participation they call: simple, consultative, projective and metaparticipation.

Simple participation would involve solely taking part in a process or activity as a spectator or performing party, but without the subject having intervened in its preparation or in decisions about its content or development. They are basically limited to following directions or responding to stimuli. Consultative participation goes one step further by hearing the subjects. They are not mere spectators, performers or users of something externally determined, but rather their views are requested on matters that affect them.

The projective participant is more than simply a user and does more than simply offer an opinion, becoming in fact a kind of agent. This is, therefore, a more demanding form of participation, requiring greater commitment and coresponsibility, with a condition for its exercise being that the participant should feel he or she is actually part of the project. It is also a more complex type of participation which, at its highest level, takes place in all the different phases of the activity: in the project definition and determination of its objectives; in its design, planning and preparation; in its management, execution and process control; and in its assessment.

The fourth and final form of this classification is called metaparticipation, and exists when the subjects themselves request, demand or generate new 
opportunities and mechanisms for participation. It appears when an individual or collective believes their participatory rights are not being recognised or when they think the established channels are insufficient or ineffective. (Trilla and Novella, 2001). As we have previously indicated, the experiences of child participation studied in our work are situated at the level of what we have called projective participation.

In relation to the preceding paragraphs, our object of study are experiences that involve "authentic" (UNICEF 2003), "effective" participation (Casas et al. 2008). As such, we exclude those forms of participation that, elsewhere, we have labelled "simple", so as to focus specifically on what we conceptualise as "projective participation" (Trilla and Novella 2001), and in all circumstances these experiences of participation had a duration of at least two years in one of the three studied areas (that is, school, leisure-time education or the municipal children's council).

Now we should specify the three educational areas outlined above. The panorama of participatory pedagogies in the twentieth century is broad and includes attempts at introducing self-government by the European movements of the New School and the Active School models (e.g., Ferrièrre, Montessori, Decroly, etc.) and their followers (e.g., Freinet, the Italian Cooperative Education Movement, etc.); the progressive education movement in the US inspired by J. Dewey and his disciples; the more radical, anti-authoritarian approaches (e.g., Summerhill, the Hamburg Schools, etc.); Carl Rogers' non-directive education; the self-management experiments of 
Institutional Pedagogy (e.g., Lobrot Lapassade, Oury and Franch); and the "just community" approach promoted by Kohlberg, etc. ${ }^{9}$

The participation experiences that we study here are more similar to those of the European movement of the New School and the Active School and to Dewey's progressive education in the US than to those of the more radical, Summerhill-type (i.e., democratic education). Apple and Beane $(2007,10)$, in their examination of "democratic schools", capture perfectly the type of experiences to which we refer: "To say that democracy rests on the consent of the governed is almost a cliché, but in a democratic school it is true that all of those directly involved in the school, including young people, have the right to participate in the process of decision making. For this reason, democratic schools are marked by widespread participation in issues of governance and policy making. Committees, councils, and other schoolwide decisionmaking groups include not only professional educators, but also young people, their parents, and other members of the school community. In classrooms, young people and teachers engage in collaborative planning, reaching decisions that respond to the concerns, aspirations, and interests of both. This kind of democratic planning, at both the school and the classroom levels, is not the 'engineering of consent' toward predetermined decisions that has too often created the illusion of democracy, but a

${ }^{9}$ For a brief but clear overview of different progressive school models (and a list of basic sources), see Puig (2001). For the more classic sources for the various democratic, antiauthoritarian and participatory pedagogies, see Dewey (1916), Neill (1960), Rogers (1969), Power, Higgins and Kohlberg (1989), Gutmann, (1999), and Apple and Beane (2007). 
genuine attempt to honor the right of people to participate in making decisions that affect their lives."

In the school experiences studied here, the participation of the young is seen in the organisation of community life and communal relations (conflict resolution, etc.) as well as in the school's pedagogical activities (the teaching methods and techniques), all of which are facilitated by means of democratic structures and procedures operating at the class-group (meetings) and the school levels (delegates, representative councils, commissions, etc.).

The leisure-time activities examined here are those that children engage in at what are known in Catalonia as esplais (Trilla et al. 2013) and which share many of the features of the scouting movement. Children enrol and attend the esplai centre regularly (usually on Saturday afternoons) throughout the year. The activities are complemented by weekend excursions and summer camps.

Finally, the municipal children's councils are participatory bodies created by a number of town and city councils, made up of local children that meet regularly to contribute, through their critical observations and suggestions, to improving the environment in which they live.

Municipal children's councils are composed of 20 to 30 boys and girls who live in the city in question and are between 9 and 12 years old. Council members come from state and private schools in the municipality and are elected by their classmates. Half of the council is renewed every year, so each councillor holds office for two years. This annual renewal of half of the council enables methods of operation and traditions that are created to be preserved and transmitted through a horizontal socialisation process. "Veterans" hand down to newcomers both the formal rules of the council as well as the rich resource of informal dynamics and shared experiences that are continuously being 
generated. Ordinary council meetings are usually held on a monthly basis, but depending on the activities being developed and the availability of members, extraordinary sessions and meetings of subgroups or commissions may be called. Each children's council has the support of an adult (appointed and contracted by the City Council) who acts as the driving force behind its operation, however, the council is fully sovereign to decide on the matters to be addressed. ${ }^{10}$.

The ones included in this study were among the first to be set up in the province of Barcelona (in the late 1990s) based, above all, on the proposals of Francesco Tonucci and his Children's City project (Tonucci 1997, 2004).

Our goal in adopting this approach was to corroborate a hypothesis that, explicitly or implicitly, is shared by all those pedagogies that seek to promote child participation: namely, the participatory experiences of childhood contribute to shaping future citizens that are critically minded, willing to participate and committed. ${ }^{11}$ Specifically, we wished to explore the retrospective view young people have of their childhood experiences (the way in which they recall them, the influences in their present lives that they attribute to them, and so on). ${ }^{12}$

${ }^{10}$ For further information about the composition, functions and operation of these councils, see: Trilla and Novella 2001, 2011.

${ }^{11}$ For further information on this idea of participatory, critical and committed citizenship, see Trilla 2010.

12 The aim of this article is to present the results of our research, which refer exclusively to the memories subjects hold of participatory experiences they had in their childhood. We present in other works, in the process of publication or already published, the results and conclusions of our other research aims: the impact on their lives and on subsequent participatory experiences which, according to the subjects' perception, those experiences had (Novella et al. 2014); and on the subjects' present conception of citizenship (Novella et al. 2013). 
In carrying out this study we combined quantitative (questionnaire) and qualitative (in-depth interviews) techniques of analysis. The questionnaire (see below for details) was given to two groups of subject, henceforth referred to as G1 and G2. G1 comprised young people between the ages of 18 and 22 who, some 10 years earlier, had had significant experience of participating in one of the three areas outlined above (that is, school, leisure-time education or the municipal children's council). To locate, identify and select the experiences for subsequent study, we drew on a number of reliable sources, including specific publications that made direct reference to them, expert advice and details provided by educational renewal and leisure-time education movements. $^{13}$

G2, which served to all intents and purposes as a control group, comprised people in the same age range that had not had these participatory experiences in their childhood, i.e., youngsters that attended not especially participatory schools or leisuretime education centres. Clearly, the sub-group corresponding to that of the children's councils does not occur in G2, since these councils are, by their very nature, essentially participatory bodies. So, just as there are schools or leisure-time education centres that do not especially foster participation, a children's council that practiced little or no participation would be a contradiction in terms.

${ }^{13}$ The research team has a proven track record studying participatory experiences in these areas, including publications (see bibliography), direction of doctoral theses (Galcerán 2000; Novella 2005; Morata 2010) and consulting. To ensure the relevance of the experiences selected, we also conducted direct observation and interviews with those responsible for the centres. 
The number of subjects included in each group and each of the three areas is detailed in Table $1 .^{14}$

\section{(Table 1)}

The questionnaire ${ }^{15}$ was divided in three sections. The first contained several items asking subjects about their memories of the days they had spent at the educational institution of reference and the influence that, in their opinion, it had exerted on their life and on different aspects of the way they are and behave today; the second section asked subjects about their subsequent participatory activity; and, the third section asked them about their current attitude to participation and citizenship.

The questionnaire items that are of greatest interest to us here are both from the first section. In the first of these we asked subjects to appraise the memory they have of participating in the experience, on a scale from 0 (very bad) to 10 (very good). In the second, an open question, subjects were asked to name the things (a maximum of three) they remembered most from the period they spent at the institution of reference.

${ }^{14}$ It was far from easy to obtain the anticipated number of participants for G1 (that is, 100 for each of the three areas), given the length of time that had passed since they had had these experiences. Nonetheless, eventually we gathered the desired number of interviewees, with the exception of former children's council members, reflecting the extremely limited number of children's councils that operated ten years ago (note the first councils in the metropolitan area of Barcelona were created around 1998). Despite the total number of possible subjects for this third area being naturally low, we were able to include 62 subjects which, in relation to the total population of possible subjects, is very high indeed.

${ }^{15}$ Construction of the questionnaire was conducted with the participation of eight experts in the field of study. Three were from our research team and five were key people in the representative organisations of one of the three fields being studied (schools, esplais and children's councils). A pilot study was subsequently carried out with a smaller number of young people to refine and validate the content and final draft of the questionnaire. 
The questionnaire delving into subjects' memories of their childhood participatory experiences was complemented with in-depth, individual, face-to-face interviews, conducted with a sub-sample of G1 (see Table 1): 29 subjects between the ages of 18 and 22 who, some 10 years earlier, had had significant experience of participating in one of the studied areas. They were distributed as follows: 10 from school, 7 from leisure-time education and 12 from municipal children's councils.

Subjects were asked to explain, justify and, in their own words, expand upon the answers they had given in the questionnaire. The script employed in the interviews followed the same line as that taken by the questionnaire: analysis and retrospective assessment of childhood participatory experiences; subsequent participatory activities, and subjects' current attitudes to participation and citizenship ${ }^{16}$.

In the section that follows we present and comment upon the main results of the study, first, through a consideration of the quantitative results obtained via the closed question on the questionnaire, and, second, through an examination of the qualitative information obtained from the interviews and the open question on the questionnaire.

\section{Memory of childhood educational experiences}

Our results show (Table 2) ${ }^{17}$ that respondents, in general, have a highly positive memory of their childhood educational experiences and that the bitter recollections we highlighted in the introduction have been largely confined to the past. Yet, marked differences are evident between those that engaged in participatory experiences (G1)

\footnotetext{
${ }^{16}$ These semi-structured interviews, lasting on average some 60 minutes, were prepared in line with the guide and conducted by members of the research team. Subsequently, inductive categorial content analysis was conducted using Atlas.ti software.

${ }^{17}$ To facilitate this analysis, results on the scale ( 0 to 10 ) were converted to the number of positive experiences: none, few, average number, quite a few and very many.
} 
and those that did not (G2).

As the table shows, fairly large majorities in both groups declared they had very good or quite good memories of the time they spent at these education centres; few subjects recalled such memories as having little or no positive value. However, the concentration of positive responses is much more marked among G1 subjects $(69.8 \%$ reported having very good memories vs. $38 \%$ in G2). The reasons for this difference are apparent in the interviews conducted with the respondents.

\section{(Table 2)}

An examination of the results by educational area reveals a similar tendency to that found in the overall results: subjects in G1 report a higher frequency of good memories than their peers in G2. In the case of participatory schools, around $67 \%$ of the subjects have very many good memories of their time spent there, a figure that falls to $38.9 \%$ in the case of those schooled at normal schools. In the case of leisure-time education this difference is even more marked. Those who attended esplais had very many $(72.3 \%)$ or quite a few $(25.0 \%)$ good memories, while in the control group only $35.7 \%$ reported having quite a few good memories of their leisure-time education. In the case of the children's councils (no controls available), approximately $80 \%$ of subjects reported having fond memories of their participation (38.7\% very many and $41.9 \%$ quite a few).

Interestingly, the difference in the quality of memories between the two groups is greater in the area of leisure-time than at school. Among G1 subjects there is a marked concentration of very many good leisure-time memories, while among G2 subjects there is a more even distribution across the scale. This pattern is repeated to some extent in the case of school, but the distributions in both groups tend to be more homogeneous. A possible explanation for this is that school environments tend, for 
better or for worse, to be more homogeneous than those of leisure-time education. Regulations, controls, traditions and even what is expected of them carry much greater weight in the case of schools than in that of leisure-time education centres.

Equally noteworthy is the fact that the most positive memories correspond (and here the difference is significant) to those reported by the G1 group in relation to their time spent in the esplais, while the G2 group record their least fond memories (albeit that they are not bad) in the equivalent area. This difference again is probably in part attributable to the greater degree of internal diversification in this educational area. A further plausible explanation concerns the subsequent links that the subjects establish with this area of their childhood memories, given that the possibilities in this regard are much greater than in the other two areas (membership of the children's council is limited to two years and the time spent at primary school is also fixed). By contrast, in the esplais the children can attend successive, age-related stages within the organisation, eventually even changing their role and becoming a group leader (or monitor). Moreover, attendance is voluntary and it is unlikely that adolescents could be forced to remain members of such an organisation against their will. In this respect, our research shows that it is the G1 subjects in this educational area (esplais) who go on to participate most in general and, also, within this area.

Thus, those that enjoyed their time in the esplais had the opportunity to maintain close, affective links to them, and indeed many chose to do so. This continuity would appear to be a key factor in the positive feedback received. For example, "As an adolescent and young person I continued to be involved with my esplai because what I did there during my childhood was a really good experience" (LT-i-G1); but, at the same time, the fact that this link was maintained serves to reactivate, strengthen and even perhaps optimise these good memories from childhood. We would seem to have 
better memories of experiences associated with a particular context the more that context continues to provide us with enjoyable experiences.

\section{The contents of the memories: what is remembered most and why}

As introduced above, we included a further item on the questionnaire to explore the contents of the subjects' memories of their childhood educational experiences. Additionally, during the interviews conducted with the G1 sub-sample that had engaged in participatory experiences we asked them to talk further about these memories. ${ }^{18}$ Most of their recollections can be placed in one of two main categories: those concerning people (and the relationships established with them) and those concerning the activities carried out. This first category can be further broken down into the way in which our subjects recall the people who exercised the role of educator ${ }^{19}$ and the relationships they built up with their peers.

\section{Educators in the memory}

In line with our quantitative results (see above), respondents seem to hold quite good memories of their educators. Indeed, by identifying the qualities they attribute to them, we are able to construct ideal profiles for educators in each of the three areas.

\footnotetext{
${ }^{18}$ From here on our discussion of the results does not distinguish between responses that were obtained via the open question in the questionnaire and those obtained from the interview. To identify the educational area and the origin of the subjects' responses, however, we use the following codes: SC (school); LT (leisure-time education), CC (children's council); $\mathbf{r}$ (reply to the open question on the questionnaire), $\mathbf{i}$ (reply recorded during the interview); and for the respondents, $\mathbf{G 1}$ and $\mathbf{G 2}$, in accordance with the earlier explanation.

${ }^{19}$ We use the word educator here in a broad sense; it includes the monitors and teachers at school as well as the monitors, facilitators or educators in the leisure-time activities or associated with the children's council.
} 


\section{General or specific}

Two types of memory can be distinguished: on the one hand, those that refer generically to their educators: "I really liked the relationships I had with my teachers" (SC-i), for instance; and on the other, those that refer to specific educators: "The good relationship I had with one teacher, which continues to this day" (SC-r-G1); "I remember one teacher who was a lot of fun" (SC-r-G2); "The music classes: I had a brilliant teacher" (SC-r-G2); "My $3^{\text {rd }}$ and $4^{\text {th }}$ year teacher: I liked her a lot" (SC-r-G2).

In the case of school memories, this second type of memory is more common among G2 subjects, while those subjects (G1) who attended participatory schools tend to have a favourable memory of the teaching staff as a whole. In some cases, the latter even recall other members of the school community, for example: "I also have good memories of the staff. I mean, from the teachers to just about anyone you could meet in the school (...) The person that opened the door, who knew us and always said hello... I don't know, it's the feeling of belonging, of like being at home" (SC-i). This last response is typical of expressions used by subjects when recalling their experiences (for example, "feeling comfortable", "feeling welcome", "like being among family", etc.) and they tend to attribute this warm, welcoming atmosphere to the work and the individual qualities of the educators.

\section{Human quality and professional competence}

In education, if it were possible to distinguish clearly between technical and methodological skills, on the one hand, and human and relationship-building qualities, on the other, it would be the latter that respondents would surely mention when identifying the educators they recall most fondly. Yet, there are those who refer explicitly to teachers that possessed both qualities in equal measure: "Good teachers, 
both as persons as well as in the way they taught" (SC-r-G2). Similarly when they describe their teachers as having been "exemplary" or "excellent", they are at the same time implicitly attributing these teachers with both qualities.

However, what the respondents refer to most when describing those educators that remain uppermost in their minds are certain human qualities, essentially those of forging relationships built on proximity, trust, support, understanding, a willingness to listen, happiness and "being treated well": "The great atmosphere among the school's pupils, teachers and parents" (SC-r-G2); “The trust that existed between pupils and teachers" (SC-r-G2); "The friendly relationship with the teachers" (SC-r-G2); "The help, camaraderie, attention and support of the monitors who stood by us through thick and thin" (LT-r-G1); "The monitors, who always gave us a smile” (LT-r-G1); "As a point of reference, the monitors - for all the good times I had with them and for the interest they showed in us" (LT-r-G1).

The educator as a model

This memory of the educator as a point of reference is a quality frequently associated with the esplai monitors, being mentioned above all by those who, as discussed above, maintained links with the institution and who, in turn, took on the role of monitors: "Now, as a monitor, it really helps me to remember the best monitors I had as points of reference. (...) To remember what they did, the proximity ... the fact they were always willing to give you advice, half-way between being like a parent and a friend. It left an impression on me and it is what, as a monitor myself, I now try to transmit to the children" (LT-i); "I was a little girl who needed my monitors a lot. And I suppose these things have made me continue [in the institution]: it was a space where I could go and tell them the things I couldn't tell my mother. This confidence that they give you ...; you feel supported by your monitors, and they end up being a model to follow." (LT-i). 
It takes all sorts

And yet, inevitably, some of the respondents harbour memories of less good-natured educators. One recalls: "Relationships of every kind with the different teachers: from getting on well to feelings of loathing” (SC-r-G2); another speaks of: "A variety of bizarre teachers" (SC-r-G2); and a third confesses to having had: "Teachers who were interested in you and others who were mad" (SC-r-G2). However, in line with the small percentage of bad memories reported above, negative reports were few and far between. On balance, it is perhaps not surprising that among the most lingering memories we find, at one extreme, excellent, open and friendly educators, while at the other, we find the mad, the contemptible, the scornful and the outrageous; yet, the more modest and the mediocre would seem to be less memorable.

\section{Peer relationships}

Likewise, the respondents reserve a special place in their memories for the classmates and friends with whom they shared their childhood experiences. Here again, they can be divided into two categories: the friendships forged in the institution and the relationships founded on the camaraderie and sense of solidarity they experienced there.

\section{Making lifelong friends}

All three areas are ideal contexts for peer encounters and, hence, for forging friendships. Unsurprisingly, many respondents refer to the friends they made during those years as constituting the most enduring elements of their memories of their childhood experiences.

Not only are these friendships well lodged in the participants' memories, they have also lasted into later life: "Friends that I still have today (...) The ones I consider really true friends, the closest, are the friends I made in the 'esplai", (LT-i); "The 
friends I've had all my life I met there" (SC-r-G2), etc. Some, moreover, recall feelings that went beyond friendship: "My first boyfriend" (SC-r-G2); "The girl I liked" (CB-r), and so on.

No great differences are perceived between G1 and G2 as regards the "making of friends", with subjects in both groups identifying the friendships they forged as being among their best memories. This comes as no surprise; the basic condition for "making friends" being simply the meeting of others and so even in the strictest, most authoritarian communities, children manage to make friends.

\section{Camaraderie, cooperation and solidarity}

In the groups and communities we are addressing, not everyone becomes friends with everyone else; yet, it is preferable that they share a sense of belonging to the same group and of mutual support. This is frequently referred to in the recollections recorded here: "What I often remember on the positive side is the sense of solidarity among classmates" (SC-i); "Belonging to a group made you consider the school was yours... And I suppose the feeling that you form part of a group is what helps you grow as a person” (SC-1); “I particularly remember the way the group stuck together” (LT-r-G1).

\section{The activities}

Having identified the memories of those who participated in those experiences, we turn now to examine just the specific details of these experiences. Below we summarise the most significant elements in their responses under three general headings; however, given that the sense and purposes of the three areas studied differ considerably, we often have to distinguish between them. 


\section{Dynamic activities}

A prominent place in the memories is taken by the activities that might be classed as dynamic. The respondents recall, above all, two types of school activity: those undertaken in specific subjects where the "putting into practice" of what they had learned turned out to be essential, even in the more traditional school contexts: "The subject of music: performing songs and playing instruments, singing in the choir and so on" (SC-r-G1); "Handicrafts: painting, building figures and other craftwork" (SC-rG1). Subjects also recalled the more dynamic, active lessons received in a range of subjects: "In the natural science classes we always practiced on real animals. For instance, we brought in animals' lungs, sheep's heads and so on" (SC-r-G1); "When we played games to get a better understanding of the language” (SC-r-G2).

In all of these instances the point was to apply (practice, experiment, build, train, etc.) what was being learned. The tasks assigned to pupils required their total and active participation, taking them well beyond their traditional tasks of listening, studying, and memorising, etc. In short, it seems that it is more memorable to be an active agent than a passive receiver of information. This was summed up graphically by one of the respondents, who remembered with special fondness those "moments in which we were made to feel the centre of attention" (SC-r-G2).

The second class of activities recalled were those conducted outside the classroom in the playground, dining hall, or when arriving and leaving school. Interestingly, these non-academic moments appear in their memories with a frequency that greatly exceeds the significance usually attributed to them: "The midday break, playing games and sharing in conversations with the monitors" (SC-r-G1); "Times in the playground when we joined in fights, games and other experiences, and when we settled our quarrels" (SC-r-G2); "The dining hall, where all the pupils from the 
different years gathered together in one space, without any kind of academic pressure" (SC-r-G2).

\section{Extraordinary activities}

In all three educational areas, a special emphasis is placed on activities that might be referred to as "extraordinary", i.e., those that break with the routine, either because of their intensity or the degree of involvement they called for, the level of motivation with which they were carried out, their innovative nature, the setting in which they were conducted (outside the normal institutional boundaries), the complexity of their organisation requiring the subjects to take an active role, or because of their external projection. We refer to visits to activity centres, going camping, going on a trip, taking part in a student exchange or in traditional festivals, cultural and sporting events, or participating in some sort of campaign, etc.

Activities of this kind seem to abound in the memories that young people have of their childhood experiences. The routine, the usual and the ordinary, despite being what we invest most real time in, remains embedded in the memory as a uniform mass; but, the extraordinary is always more memorable.

\section{Participatory activities}

Finally, we turn to look at what the respondents remember about participating in the wider community of which their centres formed a part and their involvement in the running and organisation of their activities. Unsurprisingly, it is the members of G1 who have accumulated most memories.

Former members of the children's councils - the purpose of which was to act as the mouthpiece of the young and to enable them to intervene and collaborate in improving their local environment - spoke of their involvement in the following terms: 
“... the feeling that you can change things in your town, things you don't like and that could be improved. And seeing that you have that capability, even though you're very young” (CB-i); "We made a commercial to raise people's awareness of the benefits of public transport” (CB-i); "We held meetings with various schools from areas that were extremely different, each with its own problems, and everyone was able to express their concerns and suggestions freely, knowing they were being listened to" (CB-r).

Participating in the organisation of activities and managing the life of the group drew the following comments: "All through the years of primary school, one day a week there was a small class meeting in which we had discussions and made shortand long-term proposals about the organisation of the school's premises, time, materials and activities." (SC-r-G1); "I learned how to stand up for my opinion, to defend it and to find a way to get someone to listen to me" (CB-i); "Taking part made me feel involved; the fact that it was us who had to take decisions" (CB-i); "I've learned to feel that your opinion matters and that you shouldn't keep the things you think to yourself, because maybe other people think the same as you” (CB-i). What they all seem to be saying is that they learned to participate and by recognising this they are also revalidating the basic principle of pedagogical activism: namely, the most effective way of learning how to participate is by participating.

\section{Summary}

We began this article with various testimonies in which the experience of school was recounted in a highly negative fashion; moreover, we argued that such memories were by no means the exception of those whose schooldays were lived in the $20^{\text {th }}$ century and, of course, the centuries that preceded it. However, on the basis of the data obtained in this study we can confirm that, in general, today's young people hold somewhat better memories of their schooldays. 
It is nevertheless curious that when schooling was not yet open to everyone, some of these privileged few should recall it in such negative terms. Yet, today, now that schooling is largely universal, memories tend to be far more positive. Seen in a historical perspective, this gradual extension of schooling has been accompanied by a substantial improvement in the wellbeing of its users. This progress, of course, has not always been linear; there have been - and there continue to be - sporadic reactionary periods, the fruit of adverse economic situations and retrograde education policies. However, a broad historical review clearly demonstrates the progress to which we allude.

Yet, while schooling today happily no longer resembles the abhorrent conditions of the past, not everyone recalls their experiences with equal satisfaction. Obviously, even today, there are good and bad schools: some that generate happy memories, others less so. Some of these differences have been described in the course of the preceding discussion, but one of the factors that seems to have a marked influence on just how the educational experience is recalled is the degree to which the institution was able to make its pupils feel involved in its organisation.

Our quantitative results show that young people who attended institutions that promoted participation have very good memories of them; memories that appear to be more positive than those of their peers who attended other centres. However, this finding alone is not sufficient for us to establish a strict causal relation. Undoubtedly, the quality of educational experiences depends not solely on the pupils' participation, but upon an array of diverse variables and factors that further research needs to ascertain.

This said, our qualitative results provide additional evidence that participating has a positive impact on the way school experiences are remembered. Our subjects 
explicitly acknowledge that this factor has contributed to their recalling their schooldays with satisfaction. They specifically recognise that the institutions they attended created the conditions in which they could express themselves freely and where they felt they were listened to. They also valued the fact that they could take decisions, negotiate agreements, take part in projects, involve themselves in the organisation of matters affecting the institution, and take on a range of different responsibilities, all of which were a direct reflection of their ability to participate.

And attitudes and participatory skills are an essential part of the exercise of democratic citizenship. As John and Evelyn Dewey $(1915,304)$ point out:

"Responsibility for the conduct of society and government rests on every member of society. Therefore, every one must receive a training that will enable him to meet this responsibility, giving him just ideas of the condition and needs of the people collectively, and developing those qualities which will insure his doing a fair share of the work of gov-ernment. If we train our children to take orders, to do things simply because they are told to, and fail to give them confidence to act and think for themselves, we are putting an almost insurmountable obstacle in the way of overcoming the present defects of our system and of establishing the truth of democratic ideals. Our State is founded on freedom, but when we train the State of tomorrow we allow it just as little freedom as possible. Children in school must be allowed freedom so that they will know what its use means when they become the controlling body, and they must be allowed to develop active qualities of initiative, independence, and resourcefulness, before the abuses and failures of democracy will disappear." It is our hope that this paper and our study might serve to strengthen the idea that participating in childhood educational establishments is not only a democratic right 
- which in itself is sufficient to justify the concept, but also one that contributes to the quality of experiences at these establishments and, thus, to their being recalled fondly at a later date. An educational experience that is memorable has a twofold value: it served to educate the individual in its day and it continues to educate that individual each time it is recalled.

References

Alted, A., coord. 1996. Entre el pasado y el presente. Historia y Memoria. Madrid: UNED.

Apple, M. W. and J. A. Beane eds. 2007. Democratic Schools: Lessons in powerful education. $2^{\text {nd }}$ ed. Portsmouth, NH: Heinemann.

Azorín. 1972. Artículos olvidados de J. Martínez Ruiz (1894-1904). Madrid: Narcea. Baddeley, A. 2010. “Autobiographical memory.” In Memory, A. Baddeley, M. W. Eysenck and M. C. Anderson, 165-191. East Sussex: Psychology Press.

Barone, T. E. 1988. "Curriculum Platforms and Literature.” In The curriculum. Problems, Politics and Possibilities, edited by L. E. Beyer and M. W. Apple, 140-165. Albany: State University of New York Press.

Carbonell, J., R. Torrents, T. Tort and J. Trilla eds. 1987. Els grans autors i l'escola. Vic, Eumo.

Casas, F. et al. 2008. Informe sobre experiencias de participación social efectiva de niños, niñas y adolescentes. Madrid: Ministerio de Educación, Política Social y Deporte.

Castilla Del Pino, C. 2006. "La forma moral de la memoria. A modo de prólogo.” In $E l$ derecho a la memoria, edited by F. Gómez. Bilbao: Alberdania.

Craig, P., ed. 1994. The Oxford Book of Schooldays. Oxford: Oxford University Press.

Dewey, J. and E. Dewey. 1915. Schools of To-morrow. New York: E. P. Button \& Company.

Dewey, J. 1916. Democracy and Education. New York: Macmillan.

Galceran, M. 2000. "La participació en els centres de temps lliure." PhD diss., University of Barcelona, Spain.

Gutmann, A. 1999. Democratic Education. Princeton: Princeton University Press. 
Jackson, P. W. and S. Haroutinian-Gordon, eds. 1989. From Socrates to Software. The Teacher as Text and the Text as Teacher. Chicago: University of Chicago Press. Judt, T. 2010. The Memory Chalet. New York: The Penguin Press.

Lansdown, G. 2001. Promoviendo la participación de los niños en la toma de decisiones democráticas. Florencia: UNICEF Centro Innocenti.

Lass, A. N. and N. L. Tasman. 1981. Going to School. An Anthology of Prose about Teachers and Students. New York: New American Library.

Le Goff, J. 1992. History and Memory. New York: Columbia University Press.

Lomas, C. 2011. “Literatura, memoria y educación.” In Lecciones contra el olvido, edited by C. Lomas, 11-160. Barcelona: Octaedro.

Manzanero, A. L. 2008. Psicología del Testimonio. Madrid: Pirámide.

Morata, M. J. 2010. "De la Animación Sociocultural al Desarrollo Comunitario. Su incidencia en el ocio." PhD diss., University of Barcelona, Spain.

Mudrovcic, M. I. 2005. Historia, narración y memoria. Los debates actuales en filosofía de la historia. Madrid: Akal Ediciones.

Neill, A. S. 1960. Summerhill: A Radical Approach to Child Rearing. New York: Hart Publishing Company.

Novella, A. 2005. "La Participació social de la infància a la ciutat: estudi sobre l'experiència de l'Ajuntament de Sant Feliu de Llobregat." PhD diss., University of Barcelona, Spain.

Novella, A., I. Agud, A. Llena and J. Trilla. 2013. "El concepto de ciudadanía construido por jóvenes que vivivieron expriencias de participación infantil.” Bordón. Revista de Pedagogía, 65, 3, 93-108.

Novella, A., A. Llena, E. Noguera, M. Gómez, T. Morata, J. Trilla, I, Agud and J. CifreMas. 2014. Participación infantil y construcción de la ciudadanía. Barcelona: Graó.

Power, F. K., A. Higgins, L. Kohlberg. 1989. Lawrence Kohlberg's Approach to Moral Education. New York: Columbia University Press.

Puig, J. 2001. “Alexander Neill y las pedagogías antiautoritarias”. In El legado pedagógico del siglo XX para la escuela del siglo XXI, edited by. J. Trilla, 151176. Barcelona: Graó.

Ricoeur, P. 2004. La Memoria, la Historia, el Olvido. Buenos Aires: Fondo de Cultura Económica.

Rogers, C. 1969. Freedom to Learn. Columbus, Ohio: Charles Merill. 
Shaw, B. 1910. A Treatise on Parents and Children.

$<$ http://www.gutenberg.org/files/908/908-h/908-h.htm\#link2H_4_0010>

Thompson, C. P., D. J. Herrmann and D. Bruce, eds. 1998. Autobiographical Memory.

New Jersey: Lawrence Erlbaum Associates.

Tonucci, F. 1997. La Ciudad de los Niños. Madrid: Fundación Germán Sánchez Ruipèrez.

Trilla, J. 2002. La aborrecida escuela. Barcelona: Laertes.

Trilla, J. 2010. "Propuestas conceptuales en torno al debate sobre educación para la ciudadanía." In Entre todos. Compartir la educación para la ciudadanía, edited by J. M. Puig, 77-92. Barcelona: ICE-Horsori.

Trilla, J., A. Ayuste and I. Agud. 2013. "After school activities and leisure education.” In Handbook of Child Well-being, edited by A. Ben-Arieh, F. Casas, I. Frones and J. Korbinn, 863-894. Dordrecht: Springer Science \& Business Media BV.

Trilla, J. and A. Novella. 2001. "Educación y participación social de la infancia." Revista Iberoamericana de Educación, no. 26: 137-164.

Trilla, J. and A. Novella. 2011. "Participación, democracia y formación para la ciudadanía. Los consejos de infancia.” Revista de Educación, no. 356: 23-43.

Unicef. 2003. The State of the World's Children (www.unicef.org)

Viñao, A. 2002. "Relatos y relaciones autobiográficas de profesores y maestros." In $L a$ memoria y el deseo, edited by A. Escolano and J. M. Hernández, 135-175. Valencia: Tirant lo Blanc.

Viñao, A. 2011. “Ayer y hoy de la educación en España: memorias y desmemorias.” In Lecciones contra el olvido, edited by C. Lomas, 23-60. Barcelona: Octaedro.

Woolf, V. 1931. The Waves. Moorside Press. <http://www.moorsidepress.com/virginiawoolf/the-waves/>

Zweig, S. 2001. El mundo de ayer. Memorias de un europeo [The World of Yesterday]. Barcelona: El Acantilado. 